\title{
PELATIHAN PENINGKATAN KAPASITAS PEMUDA DAN PEMBUATAN PROGRAM KERJA PADA ORGANISASI PEMUDA DESA CIBINUANG, KABUPATEN KUNINGAN
}

\author{
Roni Nursyamsu \\ Program Studi Sistem Informasi, Fakultas Ilmu Komputer \\ Universitas Kuningan, Indonesia \\ E-mail : roni.nursyamsu@uniku.ac.id
}

\begin{abstract}
The Community Service Activity / Kegiatan pengabdian kepada Masyarakat (PKM) was held in Cibinuang Village, Kuningan District, Kuningan Regency with the target of young people who are members of Karang Taruna Tunas Mekar as youth organization in Cibinuang Village. The problems faced by partner institution in this activity are: a) lack of socialization about the existence of youth organizations and their roles in the development of rural communities, b) less awareness and participation of youth in organizations, both administrator/ other members, c) training of administrators / members in making work programs have never been done. The method of implementation in this activity is active participation with stages namely 1). Seminar and discussing about the role of youth organizations, 2). Providing technical training in making organization programs, 3) Mentoring in making proposals. Seminar about the roles of youth organization for community empowerment in youth organizations in Cibinuang Village presented material in accordance with the theme. The materials presented to the participants including: the role of youth in village development, the mechanism for preparing programs and how to make proposals for effective funding requests. The training in making organization programs and activity proposals were divided into three stages, namely lectures and discussion about the role of youth organizations, providing technical training in the preparation of organization programs and making activity proposals, and mentoring in making organization programs and proposals. Based on the process PkM activities, it can be seen that 1) there were enhancing youth's understanding and awareness of their capacity in developing villages through youth organizations, 2) members and administrators of youth organizations were motivated to play an active / participating role in building themselves and their villages, 3) administrators of youth organizations to arrange a program, 4) the management of the youth organization was able to make a proposal from each organization program that will be submitted to the Cibinuang Village Government.
\end{abstract}

Keywords: Youth Capacity, Youth Organization, Organization Program

\begin{abstract}
Abstrak
Kegiatan Pengabdian Kepada Masyarakat (PKM) ini dilaksanakan di Desa Cibinuang Kecamatan Kuningan Kabupaten Kuningan dengan target pemuda-pemudi yang tergabung dalam Karang Taruna Tunas Mekar yang merupakan organisasi kepemudaan di tingkat Desa Cibinuang. Permasalahan yang dihadapi oleh lembaga mitra dalam kegiatan ini yaitu: a) kurang tersosialisasikanya eksistensi organisasi pemuda dan perannya dalam pembangunan masyarakat desa, b) kesadaran dan partisipasi pemuda dalam organisasi baik pengurus/anggota kurang, c) pelatihan pada pengurus/anggota dalam membuat program kerja belum pernah dilakukan. Metode pelaksanaan dalam kegiatan ini yaitu partisipasi aktif dengan tahapan yakni 1). Ceramah dan tanya jawab tentang peran organisasi pemuda, 2). Memberikan pelatihan teknis pembuatan program kerja, 3) Pendampingan dalam membuat proposal kegiatan. Seminar tentang peran organisasi pemuda untuk pemberdayaan masyarakat pada organisasi pemuda di Desa Cibinuang Kec. / Kab. Kuningan diisi dengan pemaparan materi yang sesuai dengan tema. Materi-materi yang disampaikan kepada peserta meliputi: peran pemuda dalam pembangunan desa, mekanisme penyusunan program kerja dan cara pembuatan proposal kegiatan untuk permintaan dana yang efektif. Pelatihan pembuatan program kerja dan proposal kegiatan dibagi menjadi tiga kegiatan, yaitu ceramah dan tanya jawab tentang peran organisasi pemuda, memberikan pelatihan teknis penyusunan program kerja dan pembuatan proposal kegiatan, dan pendampingan dalam membuat program kerja dan proposal kegiatan. Berdasarkan proses kegiatan Pengabdian Kepada Masyarakat dapat dilihat adanya 1) peningkatkan pemahaman dan kesadaran pemuda terhadap kapasitasnya dalam membangun desa melalui wadah organisasi pemuda, 2) anggota maupun pengurus organisasi kepemudaan termotivasi untuk berperan aktif/berpartisipasi dalam membangun diri maupun desanya, 3) pengurus organisasi kepemudaan dapat
\end{abstract}


menyusun program kerja, 4) pengurus organisasi kepemudaan mampu membuat proposal kegiatan dari setiap program kerja yang akan diajukan ke Pemerintah Desa Cibinuang. Kata Kunci: Kapasitas Pemuda, Organisasi Kepemudaan, Program Kerja

\section{PENDAHULUAN}

Organisasi pemuda merupakan bagian subsistem kelembagaan dalam masyarakat sebagai kelompok kegiatan pemuda. Dalam organisasi pemuda tersebut dapat dilakukan pembinaan dan pengembangan serta pemberdayaan dalam upaya mengembangkan kegiatan sosial, ekonomi pr oduktif. Pembinaan pemuda dengan mengembangkan daya tanggap mereka terhadap potensi yang dimiliki dapat direalisasikan melalui pemahaman terhadap arti pentinya sebuah organisasi pemuda. Organisasi kepemudaan dapat memberikan kontribusi pada upaya menciptakan kondisi masyarakat yang aman, tidak adanya kenakalan remaja dan pergaulan bebas serta penyakit sosial lainnya akan tereduksi. Sehubungan dengan permasalahan tersebut, pemuda perlu diberdayakan sehingga mampu meningkatkan eksistensinya yang berdaya guna dan berhasil guna serta menghasilkan generasi pembangunan.

Pengembangan organisasi pemuda sebagai wadah kegiatan dalam rangka mencapai tujuan pembangunan masyarakat sering tidak menjadi fokus dalam pembangunan masyarakat. Dalam realitasnya, organisasi pemuda mempunyai potensi membangun bangsa dan sebagai agen perubahan sosial. Keberadaannya perlu dikelola secara profesional agar memberikan kontribusi pada pembangunan daerah. Dalam lingkungan desa, terdapat banyak potensi yang dapat dikembangkan sebagai modal alternatif untuk pembangunan daerah. Permasalahan yang sering nampak bahwa para pemuda kurang mampu dalam menggali potensi yang dimiliki ataupun kurang kreatif dalam menciptakan peluang yang dapat direspon dalam lingkungan tempat tinggal mereka. Kondisi tersebut menyebabkan program kerja kurang mendapat dukungan anggotanya ataupun masyarakat setempat.

Seiring dengan kebijakan pemerintah terkait dana pendamping desa, yang pada tahun ini mengalami kenaikan yang signifikan maka pemuda mempunyai peluang untuk melakukan kegiatan pembangunan daerahnya melalui program kerja berbasis kebutuhan lokal. Hal tersebut sebagai bentuk nyata untuk menyerap dana pendamping desa yang melonjak secara signifikan. Tahun lalu (2015) dana pendamping desa untuk pembangunan sejumlah 21 trilyun dan untuk tahun 2016 sebanyak 46,9 trilyun. Realitas ini perlu direspon untuk melakukan pemberdayaan masyarakat, khususnya para pemuda. Beberapa desa di lingkungan kecamatan Kuningan, khususnya di Desa Cibinuang, keberadaan organisasi pemuda belum menunjukkan perannya dalam peningkatan kualitas masyarakatnya. Mereka kurang memanfaatkan organisasi ini sebagai wadah kegiatan dalam upaya membangun daerahnya. Dengan kondisi ini, perlu adanya intervensi melalui pemberdayaan dengan sosialisasi dalam peningkatan kesadaran akan eksistensi pemuda. Dalam satu sisi pemuda dapat memberikan kontribusi dalam pembangunan masyarakat, namun di sisi lain mereka akan menjadi beban masyarakat ketika mereka jusru tidak memberdayakan dirinya dan menjadi pengangguran. Sehingga upaya memberikan penyadaran akan perannya dalam 
membangun masyarakat sangat diperlukan. Salah satu upaya yang dapat dilakukan yaitu melalui menumbuhkan kreativitas pemuda dalam membuat program kerja sebagai bentuk keberdayaan pemuda dalam membangun daerahnya.

Pembuatan program kerja diperlukan pemahaman terhadap ruang lingkup potensi yang dimiliki lingkungan desa. Penerapan manajemen strategis dalam pengelolaannya diharapkan akan menghasilkan program kerja yang tepat, sesuai dengan kebutuhan serta potensi sumber daya yang dimiliki oleh desa, sebagai modal dalam membangun desanya. Dalam konsep manajemen strategis meliputi bagaimana sebuah organisasi membuat perencanaan yang strategis, mengkoordinasi dan implementasi program serta evaluasinya. Permasalahan yang sering dialami adalah kesulitan merancang jenis program kegiatan yang didukung oleh anggota masyarakat, khususnya para pemudanya.

Beberapa kondisi Desa Cibinuang adalah wawasan dan pengalaman dalam membuat program kerja yang mengakses sumber daya lokal sangat kurang. Kondisi ini menjadi fenomena di Desa Cibinuang. Hal tersebut disinyalir karena kurang informasi dan sosialisasi peran organisasi pemuda dalam membangun warganya. Selain itu anggota masyarakat desa yang telah tergabung dalam organisasi pemuda cenderung juga kurang aktif membuat program kerja. Hal tersebut menyebabkan program kerja kurang sesuai dengan kebutuhan, dan kegiatan sifatnya insidental. Anggota organisasi pemuda juga belum aktif dalam berbagai kegiatan untuk meningkatkan produktivitas dan kesejahteraannya, sementara para pengurus organisasi kurang mempunyai kemampuan membuat program kerja sesuai dengan kebutuhan real warganya. Realitas tersebut sangat mendesak untuk segera dilakukannya pemberdayaan para pemuda melalui kegiatan pelatihan. Lebih jauh, mereka dapat memberikan kontribusi bersamasama dengan pemerintahan desa dan lembaga-lembaga desa lainnya.

Permasalahan Mitra, Berdasarkan uraian di atas, permasalahan yang dihadapi oleh lembaga mitra dalam kegiatan ini dapat dirumuskan sebagai berikut:

1. Kurang tersosialisasi eksistensi organisasi pemuda dan perannya dalam pembangunan masyarakat desa.

2. Kesadaran dan partisipasi pemuda dalam organisasi baik pengurus/anggota kurang.

3. Pelatihan pada pengurus/anggota dalam membuat program kerja belum pernah dilakukan.

4. Kurangnya kemampuan membuat proposal yang representatif.

Solusi Permasalahan, Adapun solusi dari permasalahan yang ada pada organisasi mitra kegiatan pengabdian pada masyarakat ini adalah:

1. Meningkatkan pemahaman tentang eksistensi peran organisasi pemuda dalam Pembangunan.

2. Meningkatkan kesadaran pemuda untuk dapat berpartisipasi dalam kegiatan dan atau menjadi anggota maupun pengurus yang aktif. 
3. Meningkatkan pemahaman dan keterampilan pengurus/anggota karang taruna untuk menentukan program kerja yang fisibel untuk dilaksanakan.

4. Meningkatkan keterampilan membuat proposal kegiatan dalam organisasi.

Target Luaran, Luaran dari kegiatan pengabdian kepada masyarakat ini adalah sebagai berikut:

1. Peningkatan pemahaman dan kesadaran pemuda terhadap kapasitasnya dalam membangun desa melalui wadah organisasi pemuda..

2. Penyuluhan dan pelatihan yang diselengarakan akan memberikan dampak yang baik terhadap peningkatan kualitas sumber daya manusia di organisasi karang taruna Desa Cibinuang.

3. Materi pelatihan peran pemuda dan penyusunan program kerja.

4. Target lainnya yang diharapkan bagi tim pengabdian kepada masyarakat ini adalah sebagai bentuk pelaksanaan Thri Dharma perguruan tinggi dan sebagai rasa bentuk kepedulian terhadap pemberdayaan masyarakat.

Manfaat dan Dampak Sosial, Berdasarkan hasil kajian situasi dan permasalahan yang ada di organisasi kepemudaan Desa Cibinuang, kegiatan pengabdian masyarakat ini diharapkan dapat memnberikan manfaat sebagai berikut:

1. Terbukanya wawasan dan pola pikir pengurus dan anggota Karang Taruna Tunas Mekar Desa Cibinuang Kec. /Kab. Kuningan tentang kapasitasnya dalam membangun desa melalui wadah organisasi pemuda.

2. Anggota maupun pengurus Karang Taruna Tunas Mekar Desa Cibinuang Kec. /Kab. Kuningan dapat berperan aktif/berpartisipasi aktif dalam membangun diri maupun desanya.

3. Pengurus dan anggota Karang Taruna Tunas Mekar Desa Cibinuang Kec. /Kab.

Kuningan mampu menyusun program kerja organisasi pemuda.

4. Pengurus dan anggota Karang Taruna Tunas Mekar Desa Cibinuang Kec. /Kab.

Kuningan mampu menyusun proposal kegiatan yang akan diajukan kepada

Pemerintah Desa Cibinuang maupun pihak luar dalam rangka implementasi program kerja organisasi kepemudaan.

\section{METODE PELAKSANAAN}

Berdasarkan permasalahan yang ditemukan dan dirumuskan, maka kerangka pemecahan masalah yang dilakukan melalui kegiatan Pengabdian Pada Masyarakat ini adalah pelatihan peningkatan kapasitas pemuda dan pembuatan program kerja pada organisasi pemuda di Desa Cibinuang Kecamatan/Kabupaten Kuningan. Metode dalam kegiatan pengabdian masyarakat ini adalah partisipasi aktif dengan tahapan-tahapan kegiatan yang dilaksanakan adalah sebagai berikut:

1. Ceramah dan tanya jawab tentang peran organisasi pemuda;

2. Memberikan pelatihan teknis pembuatan program kerja;

3. Pendampingan dalam membuat proposal kegiatan. 


\section{HASIL DAN PEMBAHASAN}

Kegiatan pengabdian kepada masyarakat dilaksanakan sesuai dengan rencana yang telah ditetapkan. Peserta juga mengikuti kegiatan hingga selesai. Mereka terlihat antusias dan menyimak materi yang disampaikan oleh tim Pengabdian Pada Masyarakat. Beberapa peserta mengajukan pertanyaan terkait materi dan permasalahan-permasalahan yang muncul di dalam upaya melaksanakan kegiatan organisasi. Antusiasme peserta terhadap tema dan materi yang disampaikan juga terlihat dari kehadiran peserta yang mencapai 30 orang atau $100 \%$. Hal ini menunjukkan ketertarikan peserta terhadap materi yang disampaikan. Peserta juga mengikuti keseluruhan kegiatan, baik sesi pertama, kedua, dan terakhir dengan sangat antusias.
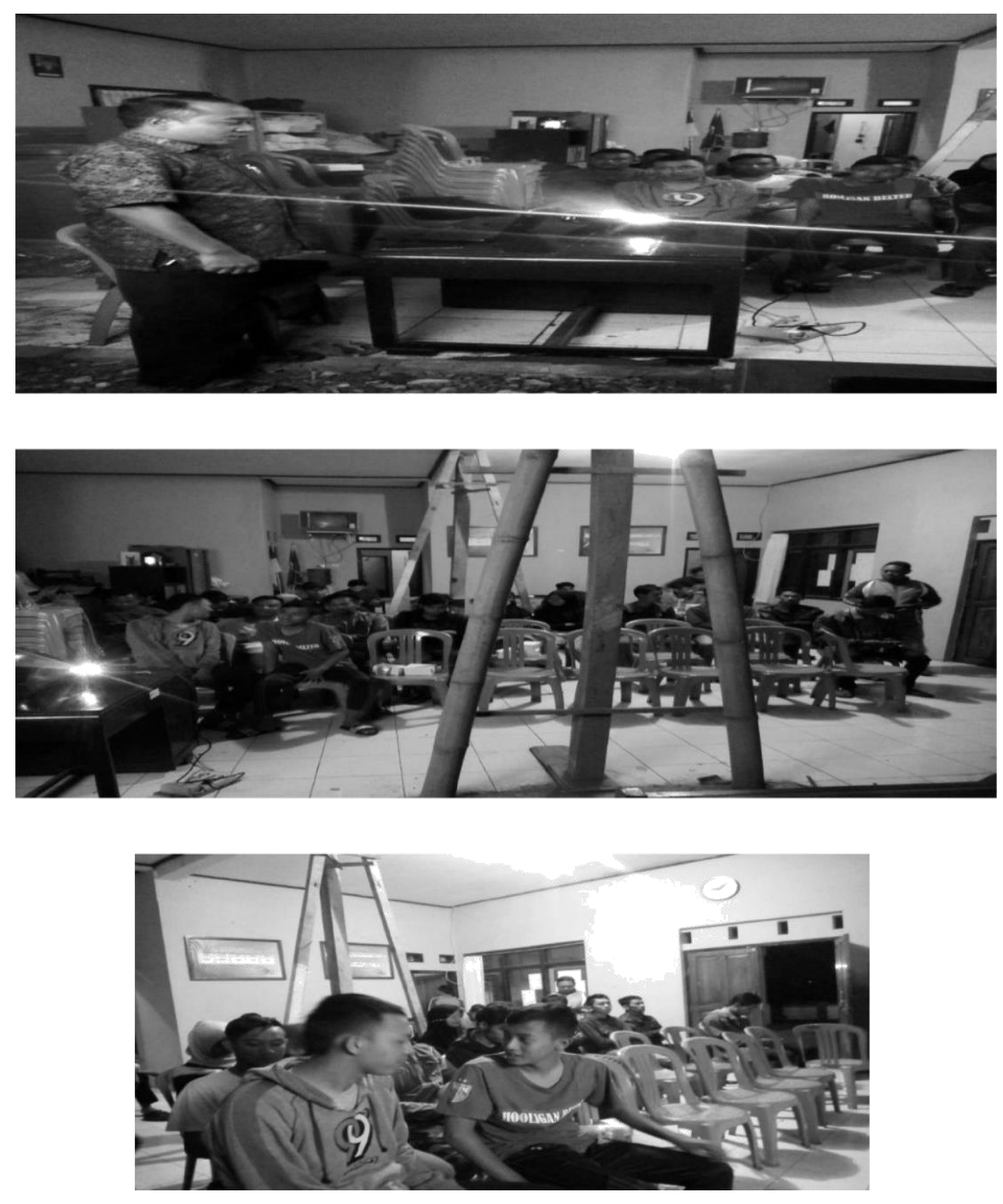

Gambar 1, 2, 3 Pelaksanaan Pelatihan, Diskusi Program Kerja Karang Taruna Tunas Mekar 
Pelatihan dilaksanakan dalam tiga jenis kegiatan, sesuai dengan metode yang direncanakan sebelumnya. Kegiatan pertama yaitu ceramah dan tanya jawab tentang peran organisasi pemuda. Kegiatan ini berupaya memberikan pemahaman dan pengetahuan, dan gambaran mengenai pentingnya organisasi pemuda dan bagaimana mengupayakan agar organisasi berjalan dengan menyelenggarakan berbagai kegiatan, baik sosial maupun ekonomi. Kegiatan ini sekaligus mendorong semangat pemuda untuk tidak pantang menyerah dan selalu kreatif menemukan ide baru. Sharing informasi dengan tim pengabdi memberikan efek yang positif karena permasalahanpermasalahan terkait kegiatan organisasi pemuda yang muncul dapat dicari solusinya, terutama yang berkaitan dengan pendanaan kegiatan yang ingin diselenggarakan.

Setelah dilakukan sharing, dilanjutkan kegiatan pelatihan teknis penyusunan program kerja dan pembuatan proposal. Peserta dibagi menjadi empat kelompok sesuai dengan bidang kerja di struktur organisasi kepemudaan, masing-masing kelompok harus mendiskusikan ide yang memungkinkan untuk diangkat menjadi program kerja organisasi pemuda. Kemudian satu dari program kerja yang telah dibuat tersebut dibuat rancangan proposal kegiatan yang ingin diajukan. Kegiatan pelatihan ini mengakomodasi ide-ide yang unik dan kreatif dari masing-masing anggota kelompok. Setiap peserta dalam kelompok juga memberikan masukan dan pertimbangan dari beberapa ide yang dirumuskan. Dengan demikian setiap anggota punya keleluasaan untuk berpikir kreatif dan menyampaikan pandangannya. Tim pengabdi membantu mengarahkan dan sharing dalam proses penyusunan draft program kerja oleh peserta.

Kegiatan terakhir yaitu pendampingan dalam pembuatan proposal lengkap. Kegiatan ini menindaklanjuti draft proposal kegiatan yang telah dihasilkan oleh kelompok peserta. Tim pengabdi bersama-sama dengan kelompok peserta memilih salah satu dari draft yang telah dihasilkan oleh masing-masing kelompok. Pemilihan didasarkan pada pertimbangan kemenarikan ide serta kemampuan peserta untuk merealisasikan kegiatan yang direncanakan. Setelah masing-masing kelompok terpilih satu draft, mereka menyusun proposal secara lengkap. Tim pengabdi bertugas untuk memberikan masukan-masukan selama proses penyusunan proposal oleh kelompok pemuda. Materi-materi yang disampaikan oleh tim PPM menjadi modal bagi peserta pelatihan untuk lebih kreatif dan memberikan kontribusi pada organisasi dengan lebih baik. Berdasarkan hasil pembahasan, dapat dikatakan bahwa kegiatan pelatihan terlaksana dengan baik dan memberikan manfaat bagi para peserta. Pemilihan materi dirasakan sesuai dan bermanfaat dalam rangka meningkatkan pemahaman tentang peran pemuda dalam pembangunan desa dan pemberdayaan masyarakat serta menghasilkan program kerja organisasi dan proposal kegiatan untuk pemberdayaan masyarakat pada organisasi pemuda.

Secara lebih rinci, berdasarkan pengamatan terhadap proses kegiatan Pengabdian Pada Masyarakat, dapat disampaikan beberapa hal penting sebagai berikut:

1. Pelatihan ini telah dapat dilaksanakan dengan baik. Pelatihan dihadiri oleh 30 orang peserta atau 100\% yang merupakan pemuda di Desa Cibinuang Kec. /Kab. Kuningan. 
2. Peserta dapat menerima materi pelatihan dengan baik dan kegiatan pelatihan juga mendapatkan respon yang sangat positif. Hal tersebut dapat dilihat dari tanggapan peserta pada saat pelatihan. Materi pelatihan sudah disesuaikan dan mengarah pada kebutuhan di lapangan, sehingga penerimaan dan kebermanfaatannya menjadi lebih baik.

3. Pelatihan penyusunan program kerja dan proposal kegiatan untuk pemberdayaan masyarakat pada organisasi pemuda ini direspon/ditanggapi dengan sangat baik oleh para peserta. Peserta pelatihan menyatakan bahwa mereka mendapatkan tambahan pengetahuan dan manfaat yang besar dari pelatihan ini. Peserta juga berharap agar pada kesempatan yang akan datang kegiatan seperti ini dilanjutkan sehingga dapat memberikan manfaat bagi para pemuda.

4. Hasil dari pelatihan ini berupa program kerja dan proposal kegiatan yang siap untuk diajukan kepada pemerintah desa, dan diharapkan benar-benar diproses dan disetujui sehingga rencana kegiatan yang dirancang benar-benar dapat direalisasikan.

Ada beberapa faktor-faktor yang menjadi pendukung kegiatan pelatihan ini yaitu antara lain:

1. Keterbukaan dari para pemuda terhadap kegiatan pelatihan yang diselenggarakan oleh tim Pengabdian Pada Masayarakat. Hal ini terlihat dari antusias dan semangat para peserta saat pelaksanaan pelatihan. Padahal kegiatan dilakukan beberapa kali, tetapi hal tersebut tidak mengurangi semangat peserta untuk mengikuti kegiatan hingga akhir.

2. Antusisme peserta yang tinggi, ditandai kehadiran peserta mencapai $100 \%$. Antusiasme peserta juga terlihat dari perhatian yang diberikan pada saat penyampaian materi, pada saat diskusi untuk merumuskan ide dan penyusunan draft program kerja dan proposal kegiatan.

3. Kegiatan pelatihan peningkatan peran pemuda dan penyusunan program kerja dan proposal kegiatan untuk pemberdayaan masyarakat pada organisasi pemuda telah menghasilkan program kerja dan sampel proposal yang siap diajukan dan direalisasikan.

Selain faktor pendukung, penulis juga menemukan beberapa faktor yang menjadi penghambat kegiatan pelatihan ini antara lain:

1. Pelaksanaan kegiatan Pengabdian Pada Masyarakat agak mundur dari jadwal yang direncanakan karena peserta juga memiliki kesibukan lain sehingga kesulitan menyamakan jadwal. Namun hal itu tidak sampai menghambat kegiatan pelatihan.

2. Dalam pelaksanaan diskusi kelompok kecil, masih terlihat anggota kelompok yang pasif, dan tidak memberikan ide/masukan kreatif. 


\section{SIMPULAN}

Berdasarkan hasil pelaksanaan pelatihan, diambil beberapa kesimpulan sebagai berikut:

1. Kegiatan Pengabdian Pada Masyarakat berhasil mensosialisasikan eksistensi peran organisasi pemuda dalam pembangunan

2. Kegiatan telah berhasil memberikan kesadaran warga untuk dapat berpartisipasi dalam kegiatan/menjadi anggota dan pengurus yang aktif dalam organisasi kepemudaan.

3. Kegiatan pelatihan berhasil mendorong pemuda ataupun anggota organisasi untuk menyusun dan menentukan program kerja yang mungkin untuk dilaksanakan.

4. Kegiatan pelatihan telah memberikan keterampilan membuat proposal dalam organisasi pemuda.

\section{SARAN}

Saran-saran yang dapat dikemukakan berkaitan dengan pelatihan ini sebagai berikut:

1. Perlu diakomodasi ide-ide dari pemuda untuk melaksanakan kegiatan dalam rangka pemberdayaan masyarakat. Salah satunya dengan cara melakukan koordinasi dan sharing informasi secara rutin dan berkelanjutan.

2. Rencana kegiatan yang telah dibuat proposalnya, diharapkan dapat ditindaklanjuti sehingga kemanfaatannya benar-benar ada.

3. Perlu diadakan kegiatan sejenis dengan tema dan permasalahan yang berbeda sehingga organisasi pemuda dapat lebih berkembang lagi.

\section{UCAPAN TERIMA KASIH}

Penulis ucapkan terima kasih kepada telah diberikan sehingga terselenggaranya kegiatan pengabdian ini. Kegiatan pengabdian ini dibiayai Universitas Kuningan Berdasarkan Surat Persetujuan Rektor No. 81.39/SPK/LPPM.PM-UNIKU/KNG/2018 Tanggal 8 Juni 2018.

\section{DAFTAR PUSTAKA}

Adi Fahrudin, .Pemberdayaan Partisipasi \& Penguatan Kapasitas Masyarakat. Bandung.

Faizal Basri, 2005. Perencanaan Strategis Bagi Organisasi Nirlaba. Media Grafika Jakarta.

Friedman, John. 1992. Empowerment, The Politics of Alternati Development. Hongkong:

Graphicraft Typesetters Ltd.

Hersey, Paul, et al, Management Of Organizational Behaviour, Utilizing Human Resources. California: Prantice Hall, International, Inc.

Undang Undang RI No. 23 Tahun 2014 tentang Pemerintahan Daerah. 